\title{
Central Obesity and Stress- Predisposing Factors to Hypertension among Health Workers in Jos University Teaching Hospital, Plateau State, Nigeria
}

\author{
Oluwasiji 0 Olaitan ${ }^{1,2 *}$, Omoniyi I Olanrewaju ${ }^{3}$, Funmi 0 Akinmoladun ${ }^{1}$ and Grace T Fadupin ${ }^{2}$ \\ ${ }^{1}$ Nutrition \& Dietetics unit, Department of Food Science \& Technology, Wesley University, Ondo, Nigeria \\ ${ }^{2}$ Department of Human Nutrition, University of Ibadan, Nigeria \\ ${ }^{3}$ Rufus Giwa Polytechnic, Owo, Nigeria
}

Submission: January 11, 2020; Published: February 18, 2020

*Corresponding author: Oluwasiji O Olaitan, Department of Food Science \& Technology, Wesley University, Ondo, Nigeria

\begin{abstract}
Central obesity poses more threat to human health than general obesity and stress increases its presentation. This study assessed prevalence of central obesity and stress, and their association with hypertension. Two hundred and eighty-three health workers in Jos Teaching Hospital, Plateau State, Nigeria were randomly selected. Socio-demographic characteristics and lifestyles (physical activity, alcohol intake, smoking and stress) were evaluated by semi-structured and International Stress Management Association Questionnaire. Central obesity was determined by waist circumference. Crude overweight, obesity and blood pressure were assessed by Body Mass Index, Body fat percentage and digital sphygmomanometer respectively. Hypertension was defined as BP $=140 / 90 \mathrm{mmHg}$. Descriptive and inferential statistics were performed and significance was set at $\mathrm{p}<0.05$. Study participants were $32 \%$ males and $68 \%$ females. Mean age was $37 \pm 9.5$ years. Clinical and non-clinical workers were $37.5 \%$ and $62.5 \%$ respectively. Majority did not drink alcohol (78.1\%) neither smoke cigarette (97.5\%) but 55.1\% did not engage in physical fitness. Central obesity, Crude overweight/obesity, at risk waist-hip ratio, excess body fat, prehypertension, hypertension were $47.3 \%$, $49.5 \%, 43.1 \%, 61.1 \%, 20.1 \%$ and $30.1 \%$ respectively. Large proportion $(60.9 \%)$ experienced moderate to high stress. Significant association was observed between Body Mass Index (BMI) and stress ( $\mathrm{p}=0.011)$, Body fat and stress ( $\mathrm{p}=0.025)$, systolic pressure and BMI ( $\mathrm{p}=0.000)$, and diastolic pressure and BMI $(\mathrm{p}=0.000)$. Central obesity and stress are prevalent among health workers especially females. This predisposes them to hypertension and other metabolic disorders. Policy on appropriate workload and recreational activities for wellbeing of health workers should be promoted by Health Policy makers in Nigeria.
\end{abstract}

Keywords: Central obesity; Stress; Hypertension; Health workers

Abbreviations: WC: Waist Circumference; BMI: Body Mass Index; WHR: Waist-Hip Ratio; ISMA: International Stress Management Association; SPSS: Social Package for Social Sciences; BP: Blood Pressure

\section{Introduction}

Obesity is increasing worldwide at alarming rate. Currently, $13 \%$ of adults globally and $8.1-22.2 \%$ Nigerian adults are obese [1,2]. Central obesity also known as visceral or abdominal obesity poses more threat to human health than general obesity. Irrespective of other fat deposits in the body, central obesity is found to contribute $20 \%$ global metabolic syndrome which includes systemic inflammation, hyperlipidaemia, insulin resistance and cardiovascular disease, even among individuals with normal weight [3]. Stress predisposes to obesity through hormonal response especially excess cortisol production leading to deposit of white adipose cells and increased appetite which make many stressed individuals to engage in consumption of foods high in calorie, fat and sugars as coping strategy $[3,4]$. Demand and shift nature of work of healthcare providers affect their sleep quality, influence their dietary habit and recreational activities [5,6]. Stress alongside influences eating pattern and 
capable of contributing to excessive body weight gain and high blood pressure [6]. This study assessed prevalence of central obesity and stress, and their association with hypertension among health workers in Jos University Teaching Hospital, Jos, Plateau State, Nigeria.

\section{Materials and Methods}

\section{Study location and design}

A cross-sectional study was conducted in Jos University Teaching Hospital, Plateau State, Nigeria. It accommodates more than 60 percent of the doctors in the entire North central region, and offers various services such as research, teaching, consultation and clinical services. Its health service providers are over 1000 and about 500 non-clinical staff strength.

\section{Sample size calculation}

Sample size was calculated using statistical formula by Araoye, 2008 and a prevalence of hypertension of $23.3 \%$ among employees of a tertiary hospital in Yenagoa, Bayelsa state, Nigeria [7]. The minimum sample size calculated was 275.

\section{Study population and sampling methodology}

Two hundred and eighty-three (283) health workers who gave informed consent were randomly selected to participate in the study. Pregnant women and sick staff were excluded. Ethical approval for the study was obtained from the Ethic committee of Jos University Teaching Hospital, Jos. The study participants also gave verbal consent to participate in the study after they have been informed about objectives of the study.

\section{Data collection}

A semi-structured, self-administered questionnaire was developed to assess socio-demographic characteristics, medical history and lifestyles (alcohol intake, smoking and physical activity) of the respondents. Weight ( $\mathrm{kg})$, height $(\mathrm{m})$, Waist
Circumference (WC) in $\mathrm{cm}$, hip waist circumference in $\mathrm{cm}$ and body fat (\%) were measured by portable bathroom weighing scale (HANSON model), stadiometer, non-stretchable measuring tape and by BIA device (Omron BF-212) respectively. Body Mass Index (BMI) and Waist-Hip Ratio (WHR) were calculated. International Stress Management Association (ISMA) questionnaire consisting twenty (20) questions was used to evaluate stress levels of the respondents. Blood pressure (BP) was measured on the right arm by digital sphygmomanometer while respondents were on seat after at least 5 mins of rest. Overall obesity was defined as BMI $\geq 30 \mathrm{~kg} / \mathrm{m}^{2}$. Central obesity was defined as $\mathrm{WC}>88 \mathrm{~cm}$ for women and $>102 \mathrm{~cm}$ for men; WHR $\geq 0.90$ for men and $\geq 0.85$ [8]. Excess body fat was defined as percentage body fat $\geq 32.0 \%$ (females) and $\geq 21.7 \%$ (males) [9-11]. Hypertension was defined as BP $\geq 140 / 90 \mathrm{mmHg}$ [12]. Respondents who scored 4 points or less were regarded to have low stress level. Those who scored 5 - 13 points were regarded as having moderate stress level while 14 points and above define high stress level. Data obtained were analyzed by Social Package for Social Sciences (SPSS) version 20.0. Data were described by mean, standard deviation, frequency and percentage. Chi-square was employed to determine associations. Level of significance was $\mathrm{p}<0.05$.

\section{Results}

\section{Socio-demographic characteristics of participants}

The study participants were 32\% males and 68\% females. Their mean age was $36.8 \pm 9.63$ years. More than half $(64.3 \%)$ of them were within age of 30-49years. Large proportions (67.5\%) were married. Medical practitioners (medical doctors, Nurses, Dieticians, Physiotherapists, Pharmacists, Medical lab scientists, Dental Technologists) were $33.6 \%$. Non-medical workers (administrative officers, security guards, cooks, cleaners, laundry workers) and interns were $65.0 \%$ and $1.4 \%$ respectively (Table 1).

Table 1: Socio-demographic characteristics, lifestyle \& medical history of participants.

\begin{tabular}{|c|c|c|c|}
\hline Variables & Male 91 (32.2\%) & Female 192 (67.8\%) & Total 283 (100\%) \\
\hline Age (Years) & & & $37(9.63)$ \\
\hline Mean (SD) & & & $71(25.1)$ \\
\hline $20-29$ & $20(28.2)$ & $51(71.8)$ & $109(38.5)$ \\
\hline $30-39$ & $48(44.0)$ & $61(56.0)$ & $73(25.8)$ \\
\hline $40-49$ & $21(28.8)$ & $52(71.2)$ & $30(10.6)$ \\
\hline$\geq 50$ & $2(6.7)$ & $28(93.3)$ & $71(25.1)$ \\
\hline Marital Status & & & $191(67.5)$ \\
\hline Single & $29(40.8)$ & $42(59.2)$ & $17(6.0)$ \\
\hline Married & $47(24.6)$ & $144(75.4)$ & $04(1.4)$ \\
\hline Divorced & $15(88.2)$ & $4(11.8)$ & \\
\hline Widowed & $0(0.0)$ & & \\
\hline
\end{tabular}




\section{Current Research in Diabetes \& Obesity Journal}

\begin{tabular}{|c|c|c|c|}
\hline \multicolumn{4}{|l|}{ Occupation } \\
\hline Medical Doctors & $8(66.7)$ & $4(33.3)$ & $12(4.2)$ \\
\hline Nurses & $2(13.3)$ & $13(86.7)$ & $15(5.3)$ \\
\hline Dieticians & $7(26.9)$ & 19(73.1) & $26(9.2)$ \\
\hline Physiotherapists & $4(44.4)$ & $5(55.6)$ & $9(3.2)$ \\
\hline Pharmacists & $11(84.6)$ & $2(15.4)$ & $13(4.6)$ \\
\hline Medical lab scientists & $8(44.4)$ & $10(55.6)$ & $18(6.4)$ \\
\hline Dental Technologists & $0(0.0)$ & $2(100.0)$ & $2(0.7)$ \\
\hline Interns & $0(0.0)$ & $4(100.0)$ & $4(1.4)$ \\
\hline Non-clinical & $51(27.7)$ & $133(72.3)$ & $184(65.0)$ \\
\hline \multicolumn{4}{|l|}{ Alcohol Intake } \\
\hline Yes & $13(21.3)$ & 48(78.7) & $61(21.6)$ \\
\hline No & $78(355.1)$ & $144(64.9)$ & $222(78.4)$ \\
\hline \multicolumn{4}{|l|}{ Cigarette Smoking } \\
\hline Yes & $3(42.9)$ & $4(57.1)$ & $7(2.5)$ \\
\hline No & $88(31.9$ & $188(68.1)$ & $276(97.5)$ \\
\hline \multicolumn{4}{|l|}{ Type of Physical Exercise } \\
\hline Low intensity & $36(31.9)$ & $77(68.1)$ & 113(29.9) \\
\hline High intensity & $4(28.6)$ & $10(71.4)$ & $14(4.9)$ \\
\hline None & $51(32.7 .6)$ & $105(67.3)$ & $156(55.1)$ \\
\hline \multicolumn{4}{|c|}{$\begin{array}{l}\text { Participants' Parents with chronic } \\
\text { disease }\end{array}$} \\
\hline Father/Grandfather & $21(25.0)$ & $63(75.0)$ & $84(29.7)$ \\
\hline Mother/grandmother & $22(29.3)$ & $53(70.7)$ & $75(26.5)$ \\
\hline None of the two & $48(63.2)$ & $76(36.8)$ & $124(43.8)$ \\
\hline \multicolumn{4}{|c|}{$\begin{array}{l}\text { Participants' Current Diseased } \\
\text { Conditions }\end{array}$} \\
\hline None & $85(32.6)$ & $176(67.4)$ & $261(92.2)$ \\
\hline Arthritis & $1(33.3)$ & $2(66.7)$ & $3(1.1)$ \\
\hline Ear impairment & $0(0.0)$ & $1(100.0)$ & $1(0.4)$ \\
\hline Migraine & $0(0.0)$ & $1(100.0)$ & $1(0.4)$ \\
\hline Postnatal hypertension & $2(28.6)$ & $5(71.4)$ & $7(2.4)$ \\
\hline Ulcer & $0(0.0)$ & $3(100.0)$ & $3(1.1)$ \\
\hline HBP/Rhinosinusitis & $1(100.0)$ & $0(0.0)$ & $1(0.4)$ \\
\hline Diabetes & $0(0.0)$ & $4(100.0)$ & $4(1.4)$ \\
\hline HIV & $2(100.0)$ & $0(0.0)$ & $2(0.6)$ \\
\hline
\end{tabular}

Nutritional status, lifestyle and medical history of participants

Figure 1 presents the nutritional status of the participants. Based on Body Mass Index (BMI) classification, participants having underweight were $3.5 \%$. Those with normal weight were $47.0 \%$. Overweight, obesity, central obesity and excess body fat accounted for $37.5 \%, 12.0 \%, 47.3 \%$ and $61.1 \%$ respectively. Only
$21.6 \%$ participants took alcohol and few (2.5\%) smoked cigarette regularly. Only $4.9 \%$ participants engaged in high intense physical exercise, $29.9 \%$ having low intense physical exercise every week but more than half $(55.1 \%)$ did not engage in physical fitness. About $7.5 \%$ participants were highly stressed. More than half $(62.5 \%)$ has moderate stress, and $30.0 \%$ had low stress (Figure 2). Large proportion $(92.2 \%)$ of participants claimed not to be 


\section{Current Research in Diabetes \& Obesity Journal}

suffering from any chronic disease. Prevalence of prehypertension and hypertension was $20.1 \%$ and $30.1 \%$ respectively (Figure 3). Participants who had parents suffering from chronic diseases were $56.2 \%$ and only $(7.8 \%)$ of the participants reported they were suffering from diseased conditions (Table 1).

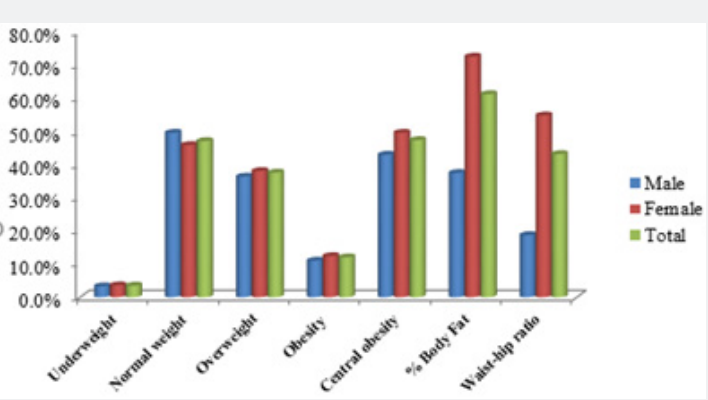

Figure 1: Nutritional status of participants.

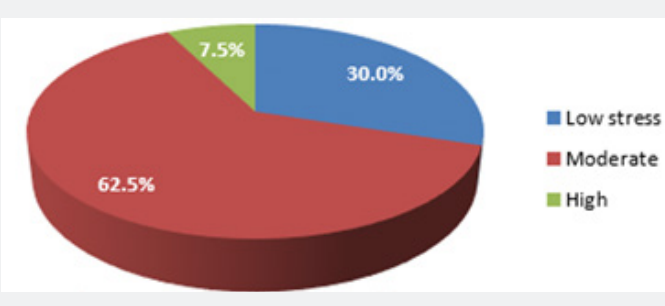

Figure 2: Stress levels of the participants.

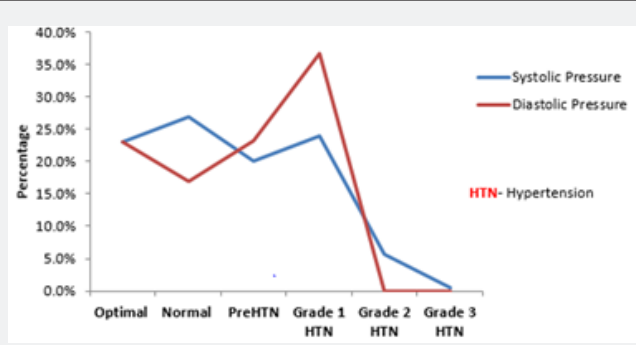

Figure 3: Blood pressure pattern of participants.

Association of obesity and stress to hypertension among Participants

Table 2: Association between variables.

\begin{tabular}{|c|c|c|}
\hline Variables & $\chi^{2}$ & P value \\
\hline BMI \& Stress & 18.98 & 0.004 \\
\hline BMI \& systolic pressure & 63.152 & 0 \\
\hline BMI \& diastolic pressure & 42.771 & 0 \\
\hline WC \& Systolic pressure & 14.031 & 0.015 \\
\hline Stress \& diastolic BP & 15.182 & 0.019 \\
\hline
\end{tabular}

A significant association was observed between Body Mass Index (BMI) and stress $\left(\chi^{2}=18.980, p=0.011\right)$, systolic pressure and BMI $\left(\chi^{2}=63.152, p=0.000\right)$, diastolic pressure and BMI $\left(\chi^{2}\right.$ $=42.771 ; \mathrm{p}=0.000)$, central obesity and systolic pressure $\left(\chi^{2}\right.$
$=14.031, \mathrm{p}=0.015)$, stress and diastolic pressure $\left(\chi^{2}=15.182\right.$, $\mathrm{p}=0.019$ ) (Table 2).

\section{Discussion}

Prevalence of overall obesity $(12.0 \%)$ and central obesity $(47.3 \%)$ in this study is lower than $27.3 \%$ obesity and $49.7 \%$ central obesity reported by Iwuala et al, [13] in Lagos, Nigeria, and $27.9 \%$ obesity observed in Kenya by Ondicho et al, [14] among health workers. Obesity is capable of causing low employee's productivity, absenteeism and lack of efficiency $[15,16]$. Prevalence of obesity and overweight among the health workers in Jos Teaching Hospital is attributed to low physical activity and prevalence of work-related stress which previous studies have reported as risk factors of obesity $[17,18]$. Previous studies have established that Nigerian health workers are overweight and obese [19-21]. This study confirmed that Nigerian health workers are not only having excess weight but are experiencing central obesity which poses more threat to healthy living than general body obesity. Central obesity predisposes individual to metabolic syndromes which include systemic inflammation, hyperlipidaemia, insulin resistance and cardiovascular disease $[22,23]$ and can occur among people with normal weight [3]. Though many of the health workers in this study claimed not to have any chronic disease, but the findings show that some of them are unknowingly suffering from prehypertension and hypertension which are results of central obesity and stress. This buttresses the fact that hypertension is a silent killer which shows no symptom until there is manifestation of cardiovascular disorders [24]. Prevalence of hypertension among the health workers in this study is similar to what Owolabi et al, [25] reported among the health workforce in Baptist Medical Hospital, Ogbomoso. But, hypertension in this study is lower than $36.6 \%$ which Ojomu et $\mathrm{al}$, [19] reported among health workers in the same study location six years earlier. This indicates that hypertension is still prevailing among Nigerian health workers.

This study observed positive association between central obesity and high blood pressure. This corroborates previous studies conducted in Nigeria and abroad where hypertension and other metabolic disorders have been observed more among obese and overweight individuals than people with normal weight [2628]. Elevated waist circumference, waist-hip ratio and excess body fat predispose to metabolic disorders which include as hypertension and diabetes $[8,9]$. This study observed association between stress and Body Mass Index. This support previous five years longitudinal study conducted by Harding et al, [29] among Australian adults in which stress is associated to weight gain. Stress is known to contribute to development of abdominal obesity through the activation of hypothalamic-pituitary-adrenal (HPA) axis which elevates circulating glucocorticoids especially cortisol resulting to high blood pressure, increased heart rate, circulating catecholamines, deposit of white adipose cells and increased 


\section{Current Research in Diabetes \& Obesity Journal}

appetite in which many affected people resulted to excess intake of caloric foods [3,4.30-32]. Buss [6] also reported that stress contributed to obesity development by influencing eating pattern of nurses in United States. Health work is characterized with shift and having high patient to care provider ratio in the health institutions increase rate of exposure of health workers to more stress as being observed in this study. World Health Organization [33] has previously raised alarm on the low density of health providers in Nigeria to deliver health services for large population (1.95 per 1,000). Thus, this is leading to high workload on the available health workers who are currently suffering from workrelated stress and some metabolic syndrome unconsciously [3436].

In conclusion, this study establishes that central obesity and stress are prevalent and associated to each other and are both predisposing factors to hypertension observed among health workers in Jos University Teaching Hospital, Plateau State, Nigeria. Health sector needs to be given serious attention by the government and stakeholders in order to ensure quality health service delivery. Health policy which addresses workload commiserating human capacity in health institutions need to be made. Health workers must also deliberately be involved in recreational activities and personal routine medical check-up.

\section{Acknowledgement}

Sincere appreciation goes to the staff of Jos University Teaching Hospital, Plateau State, Nigeria who gave their consents to participate in the study.

\section{References}

1. Chukwuonye II, Chuku A, John C, Ohagwu KA, Imoh ME, et al. (2013) Prevalence of overweight and obesity in adult Nigerians - a systematic review. Diabetes, Metabolic Syndrome and Obesity 6: 43-47.

2. World Health Organisation (2018) Obesity and Overweight.

3. Paley CA, Johnson MI (2018) Abdominal obesity and metabolic syndrome: exercise as medicine? BMC Sports Science, Medicine and Rehabilitation 10(1): 7

4. van der Valk ES, Savas M, van Rossum EFC (2018) Stress and Obesity: Are there More Susceptible Individuals? Current obesity reports 7(2): 193-203.

5. Geiger-Brown J, Trinkoff A, Rogers VE (2011) The impact of work schedules, home, and work demands on self-reported sleep in registered nurses. Journal of Occupational and Environmental Medicine 53(3): 303-307.

6. Buss J (2012) Associations between Obesity and Stress and Shift work among Nurses. Workplace Health Safety 60(10): 453-458.

7. Egbi OG, Rotifa S, Jumbo J (2015) Prevalence of hypertension and its correlates among employees of a tertiary hospital in Yenagoa, Nigeria. Ann Afr Med 14: 8-17.

8. World Health Organisation (2008) Waist Circumference and Waist-Hip Ratio: Report of a WHO Expert Consultation, Geneva, Switzerland.

9. Zhu S, Wang Z, Shen W, Heymsfield SB, Heshka S (2003) Percentage body fat ranges associated with metabolic syndrome risk: results based on the third National Health and Nutrition Examination Survey (1988-1994). American Journal of Clinical Nutrition 78(2): 228-235.

10. Ashwell M, Hsieh SD (2005) Six reasons why the waist-to-height ratio is a rapid and effective global indicator for health risks of obesity andhow its use could simplify the international public health message on obesity. International Journal of Food Sciences and Nutrition 56(5): 303-307.

11. Ejike, Chukwunonso ECC, Chinwendu E Ikwuegu, Ruth C Abalogu (2015) Obesity Determined by Different Measures and its Impact on the Health-Related Quality of Life of Young-Adult Nigerians. Asian Journal of Clinical Nutrition 7(3): 64-75.

12. Chobanian AV, Bakris GL, Black HR, Cushman WC, Green LA (2003) Seventh Report of the Joint National Committee on Prevention, Detection, Evaluation, and Treatment of High Blood Pressure. Journal of American Heart Association 42(6): 1206-1252.

13. Iwuala SO, Ayankogbe OO, Olatona FA, Olamoyegun MA, Okparalgwe U, et al. (2015) Obesity among health service providers in Nigeria: danger ti long term health worker retention?. Pan African Medical Journal 22: 1.

14. Ondicho ZM, Omondi DO, Onyango AC (2016) Prevalence and Sociodemographic Factors Associated with Overweight and Obesity among Healthcare Workers in Kisumu East Sub-County, Kenya. American Journal of Medicine and Medical Sciences 6(3): 66-72.

15. Gates DM, Succop P, Brehm BJ, Gillespie GL, Sommers BD (2008) Obesity and Presenteeism: the impact of body mass index on workplace productivity. J Occup Environ Med 50(1): 39-45.

16. Oyerinde 00, Owojaiye SO (2008) Dietary, exercise lack and obesity: health consequences of civil-servants in Nigeria in "optimizing performance excellence and wellness through the changing phase of sport, recreation, medicine and exercise science" Proceedings of Fourth International Council for Health, Physical Education, Recreation, Sport and Dance (ICHPER-SD) Africa Regional Congress. 2008 Oct 14-17; Gaborone: Library Auditorium, University of Botswana.

17. Omondi DO, Othuon LO, Mbagaya GM (2007) Physical activity patterns, dietary intake and health status among university ofNairobi Lecturers in Kenya. South Africa Journal of Research Sport, Physical Education and Recreation 29(2): 87-98.

18. Holmes ME, Ekkekakis P, Eisenmann JC (2010) The physical activity, stress and metabolic syndrome triangle: a guide to unfamiliar territory for the obesity researcher. Obesity Review 11(7): 492-507.

19. Ojomu F, Kuranga SI (2013) Blood Pressure and Body Mass Index among Jos University Teaching Hospital Staff. Transnational Journal of Science and Technology 3(9): 67-83.

20. Akarolo-Anthony SN, Willett WC, Spiegelman D, Adebamowo CA (2014) Obesity epidemic has emerged among Nigerians. BMC Public Health 14: 455 .

21. Iwuala SO, Ayankogbe 00, Olatona FA, Olamoyegun MA, Okparalgwe U, et al. (2015) Obesity among health service providers in Nigeria: danger ti long term health worker retention? Pan African Medical Journal 22(1).

22. Ritchie SA, Connell JM (2007) The link between abdominal obesity, metabolic syndrome and cardiovascular disease. Nutr Metab Cardiovasc Dis 17(4): 319-326.

23. Pedersen BK, Saltin B (2015) Exercise as medicine - evidence for prescribing exercise as therapy in 26 different chronic diseases.Scand J Med Sci Sports 25(suppl 3): 1-72. 


\section{Current Research in Diabetes \& Obesity Journal}

24. Kuan HN, Adrian GS, Bryan W (2010) Pathogenesis, Risk Factors and Prevention.an article published by Elsevier Ltd. in 2010.

25. Owolabi AO, Owolabi MO, Akintayo DOO, Amole IO (2015) Hypertension prevalence and awareness among a health workforce in Nigeria. Internet Journal of Medical 10(2): 10-19.

26. Akuyam SA, Aghogho UB, Aliyu IS, Bakari AG (2009) Serum total cholesterol in hypertensive Northern Nigerians. International Journal of Medicine and Medical Sciences 1(3): 73-78.

27. Raksha G, Nandini S (2014) A Correlative Study of Hypertension with Lipid Profile. International Journal of Research in Applied, Natural and Social Sciences 2(2): 143-150.

28. Olaitan 00, Fadupin GT, Adebiyi AA (2018) Dietary pattern, lifestyle and nutritional status of hypertensive outpatients attending University College Hospital, Ibadan, Nigeria. Afr J Biomed Res 21: 29-36.

29. Hardling JL, Backholer K, Williams ED, Peeters A, Cameron AJ (2014) Psychosocial stress is positively associated with body mass index gain over 5 years: evidence from the longitudinal Aus Diab study. Obesity 22(1): 277-286

30. Steptoe A, Kunz-Ebrecht SR, Brydon L, Wardle J (2004) Centra adiposity and cortisol responses to waking in middle-aged men and women. Int J Obes Relat Metab Disord 28(9): 1168-1173.
31. Black PH (2006) The inflammatory consequences of psychologic stress: relationship to insulin resistance, obesity, atherosclerosis and diabetes mellitus, type II. Med Hypotheses 67: 879-891.

32. Donoho CJ, Weigensberg MJ, Emken BA, Hsu JW, Spruijt-Metz D (2011) Stress and abdominal Fat: Preliminary Evidence of Moderation by the Cortisol awakening Response in Hispanic Peripubertal Girls. Obesity (Silver Spring) 19(5): 946-952.

33. World Health Organization (2010) HRH Fact Sheet- Nigeria, WHO Africa Health Workforce Observatory Statistics.

34. Ritchie SA, Connell JM (2007) The link between abdominal obesity, metabolic syndrome and cardiovascular disease. Nutr Metab Cardiovasc Dis 17(4): 319-326.

35. Pedersen BK, Saltin B (2015) Exercise as medicine - evidence for prescribing exercise as therapy in 26 different chronic diseases. Scand J Med Sci Sports 25(suppl 3): 1-72.

36. Black PH (2006) The inflammatory consequences of psychologic stress: relationship to insulin resistance, obesity, atherosclerosis and diabetes mellitus, type II. Med Hypotheses 67: 879-891.

Your next submission with Juniper Publishers
will reach you the below assets
- Quality Editorial service
- Swift Peer Review
- Reprints availability
- E-prints Service
- Manuscript Podcast for convenient understanding
- Global attainment for your research
- Manuscript accessibility in different formats
( Pdf, E-pub, Full Text, Audio)
- Unceasing customer service
Track the below URL for one-step submission
https://juniperpublishers.com/online-submission.php

